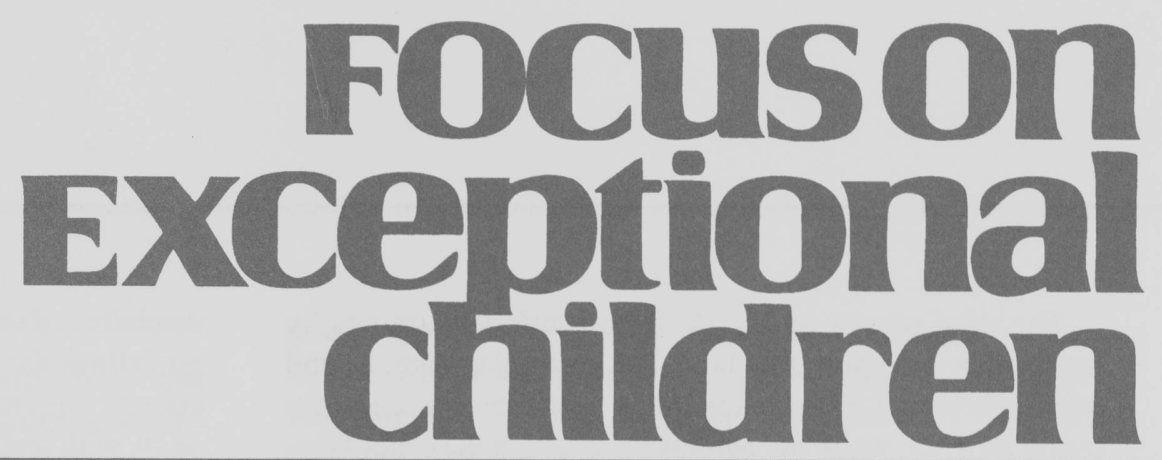

\title{
Disciplining Students with Disabilities
}

\author{
Mitchell L. Yell, Michael E. Rozalski, and Erik Drasgow
}

Discipline refers to procedures that teachers use to maintain a classroom climate conducive to learning (Walker, Colvin, \& Ramsey, 1995). Teachers generally think of discipline as techniques they can use to manage misbehavior (Curwin \& Mendler, 1988; Walker, 1995). We believe that discipline involves more than just using procedures to control student misbehavior. It also is a means to teach students about the effects of their behavior on others and to help them learn to control and manage their own behavior. Discipline should maintain an effective classroom environment and positively affect the lives of students in that classroom.

Discipline long has been an important concern of administrators, teachers, and parents. Thus, it is not surprising that courts and legislators have addressed issues regarding the use of disciplinary procedures with students in the public schools. In fact, the law has been an important force in the development of ways in which we use discipline. Therefore, we must understand the legal requirements and constraints that guide school personnel when disciplining students.

Three sources of law directly affect discipline in schools:

1. Legislation

2. Regulations

3. Litigation.

The first source of law, legislation, refers to statutes that either the U.S. Congress passes on a federal level or a state legislature passes on a state level, which become laws when they are signed by the President or a governor. The Individuals with Disabilities Education Act Amendments (IDEA) of 1997 is an example of a federal law that has affected the discipline of students with disabilities. School personnel must be aware of and follow both federal and state laws.

When Congress and state legislatures pass statutes that become laws, they delegate authority to administrative agencies to create rules that will implement the laws. These rules, called regulations, add specific information to the laws. For example, the U. S. Department of Education wrote the regulations for the IDEA ' 97 . These regulations, which took effect on May 11, 1999, provide additional detail that assist state education agencies and local school districts to carry out the provisions of the IDEA. Regulations have the force of law. This means that they must be followed and that violating a regulation is as serious as breaking the law.

Mitchell L. Yell and Erik Drasgow are affiliated with the Special Education Program at the University of South Carolina. Michael E. Rozalski is with the Special Education Program at the State University of New York at Geneseo. 
The third source of law, litigation, refers to rulings by courts that interpret the law. For example, parents and school personnel disagree regarding a student's special education program when the parents believe that the school district is not educating their child in accordance with its responsibilities under the IDEA. If the parents and the school personnel cannot agree on a solution to their problem, either party may file a lawsuit in a court. The court then is responsible for interpreting the IDEA and deciding if the school has met its legal responsibilities. Court interpretations of the IDEA are useful because they guide us on how to follow the mandates of the law. Because all three sources of law affect discipline practices in schools, school personnel should understand how they can use the procedures in a legally correct manner.

In this article we first review and analyze the legal requirements that schools must follow in disciplining all students. We then focus on the legal requirements and regulations regarding the discipline of students with disabilities found in the IDEA Amendments of 1997. We also analyze policy statements made by the Office of Special Education Programs (OSEP) of the U. S. Department of Education and the results of state-level due-process hearings regarding

\section{Focuson
Exceptional
children}

ISSN 0015-511X

FOCUS ON EXCEPTIONAL CHILDREN (USPS 203-360) is published monthly except June, July, and August as a service to teachers, special educators, curriculum specialists, administrators, and those concerned with the special education of exceptional children. This publication is annotated and indexed by the ERIC Clearinghouse on Handicapped and Gifted children for publication in the monthly Current Index to Journals in Education (CIJE) and the quarterly index, Exceptional Children Education Resources (ECER). The full text of Focus on Exceptional Children is also available in the electronic versions of the Education Index. It is also available in microfilm from Xerox University Microfilms, Ann Arbor, MI. Subscription rates: Individual, \$30 per year; institutions, \$40 per year. Copyright (C) 2001, Love Publishing Company. All rights reserved. Reproduction in whole or part without written permission is prohibited. Printed in the United States of America. Periodical postage is paid at Denver, Colorado. POSTMASTER: Send address changes to:

$$
\begin{gathered}
\text { Love Publishing Company } \\
\text { Executive and Editorial Office } \\
\text { P.O. Box } 22353 \\
\text { Denver, Colorado } 80222 \\
\text { Telephone (303) 221-7333 }
\end{gathered}
$$

Karen Harris

University of Maryland
Thomas Skrtic University of Kansas

James Shriner

University of Illinois

Erica J. Lawrence Editor
Stanley F. Love

Publisher discipline of students with disabilities. We end by discussing guidelines for school districts to follow to ensure that they comply with requirements of the law when disciplining students with and without disabilities.

\section{DISCIPLINING STUDENTS IN PUBLIC SCHOOLS}

Court decisions over the years have established courtmade or case law regarding the mutual responsibilities and obligations of educators and students in our public schools (Alexander \& Alexander, 1992). In this case law, courts have granted school authorities the power to establish and conduct educational programs. The courts' recognition of the importance of school authority over student behavior originates from the English common law concept of in loco parentis (i.e., in place of the parent). According to this concept, parents acquiesce in the control over their children when the children are placed in the charge of school personnel (Alexander \& Alexander, 1992). The principal and the teacher have the authority to teach and also to guide, correct, and discipline the child to accomplish educational objectives.

In loco parentis does not mean that the teacher stands fully in the place of parents in controlling the child during the school day. Rather, it means that school officials, acting in concert with appropriate laws and regulations, have a duty to maintain an orderly and effective learning environment through reasonable and prudent control of students (Yell, 1998). Although the concept does not have the importance it once did, it is an active legal concept that helps to define the school-student relationship.

In loco parentis implies that the teacher has a duty to maintain school order by requiring students to obey reasonable rules and commands, and to respect the rights of others. This duty includes the power to regulate and control student conduct through the development of rules, procedures, and disciplinary sanctions. Although school officials' powers in this area are broad, they are not absolute. This situation means that the courts recognize that school officials must have wide latitude in disciplinary matters; nevertheless, the procedures they use to achieve schoolwide discipline must be reasonable and humane (Valente, 2000).

School officials must understand these court-made requirements and adhere to them when developing discipline rules and procedures and applying disciplinary sanctions. These requirements include:

- Developing reasonable and appropriate school-wide discipline policies and procedures

- Extending due-process protections to students when using certain disciplinary procedures

- Ensuring that discipline sanctions are applied in a nondiscriminatory manner. 


\section{Developing Schoolwide Discipline Policies}

To maintain discipline and to operate efficiently and effectively, schools must have rules that regulate student conduct. This means that students should clearly know which behaviors are acceptable and which behaviors are prohibited. If students violate reasonable school rules by behaving in ways that are prohibited, they will be held accountable. Student accountability to rules implies that violators will be subject to disciplinary sanctions or consequences.

School officials have long known that if students understand what types of behavior are prohibited when they are in school and the consequences of engaging in these prohibited behaviors, students more likely will conduct themselves appropriately. A number of courts have addressed the issue of schoolwide discipline policies and have tended to give great authority to teachers and school officials to write rules that govern student behavior when they are in school (Yell, Katsiyannis, Bradley, \& Rozalski, 2000).

Courts also have granted school officials the authority to impose consequences on students who break school rules. When schools develop policies that regulate student conduct, the schools must be careful that the rules and consequences are rational and have a school-related purpose. Rules should be clear enough to allow students to distinguish permissible from prohibited behavior. School rules that are too vague or general may result in violating students' rights because students will not understand them clearly. In fact, if a court finds that a school rule is so vague that students may not understand what behavior is prohibited, that rule probably would be legally invalid. Thus, teachers and administrators must take care that their school rules are sufficiently clear and are communicated to students. "School-related" means that school officials may not prohibit or punish conduct that is not related to their school's educational purposes.

The most important requirement for schoolwide consequences for misconduct is that they are rational and fair. Consequences that are excessive and unsuitable to the specific circumstances may be legally invalid. This means that school officials must use reasonable means to achieve compliance with a school's rules. Reasonableness refers to procedures that are rational and fair, and not excessive or unsuitable to the educational setting. The disciplinary sanctions used in schools must not consist of penalties or restraints that are unnecessary or excessive for the achievement of proper school purposes (Hartwig \& Ruesch, 2000).

Many school officials assume that because of IDEA 97's restrictions on suspensions and expulsions, regular school district discipline policies do not apply to students with disabilities. This is a mistaken assumption. Students with disabilities who attend public school are subject to a school district's regular discipline policies and procedures (Gorn, 1999). General discipline policies, however, must be changed when applied to students in special education when the policy

- Deprives a student of special education and related services (i.e., long-term suspensions or expulsions without providing educational services)

- Triggers the procedural safeguards of the IDEA (e.g., change a student's placement without a change in the individualized education program (IEP) or without notice)

- Interferes with a student's individualized education program, behavior intervention plan (BIP), or Section 504 accommodation plan.

For example, a student's IEP might require that a certain disciplinary sanction will be used rather than the regular disciplinary sanction (e.g., in-school suspension rather than out-of-school suspension). In this situation, the student's IEP must be followed rather than using the school's regular discipline procedures.

If a student's IEP team determines that (a) he or she will be subject to the school district's regular disciplinary policy, and (b) the policy does not violate the requirements of IDEA '97, the team may use the student's IEP or BIP to affirm that the student will be subject to the district's regular discipline policies and procedures (Gorn, 1999). Including a copy of the school's discipline policy along with the IEP or BIP will accomplish this. If a student's parents agreed to the IEP or BIP, they are consenting to using the school's regular discipline policy.

The U.S. Department of Education seemingly supported this view in a comment to the final IDEA regulations: "In appropriate circumstances the IEP team...might include specific regular or alternative disciplinary measures that would result from particular infractions of school rules" (OSEP Question and Answers, 1999, p. 12589). If an IEP team decides that a student will be subject to an alternative discipline plan, this plan should be included in the student's IEP or BIP. Similarly, if a student has a Section 504 plan, this information also should be included.

\section{Extending Due-Process Procedures to Students who Are Disciplined}

The importance of education to the future of students requires that disciplinary actions (e.g., suspension, expulsion) that result in students being deprived of their education be subjected to the standards of due process (Yell, 1998). Due process is a term from the Fifth and Fourteenth Amendments to the U. S. Constitution that refers to procedures that must be undertaken to ensure the reasonable, fair, and equitable 
application and administration of the law (Huefner, 2000). In an educational setting, the purpose of due process procedures is to ensure that official decisions are made in a fair and impartial manner.

In Goss v. Lopez (1975; hereafter, Goss), the U.S. Supreme Court held that when school officials use disciplinary procedures, such as suspension, that remove students from the school environment for up to 10 days (i.e., shortterm suspensions), the suspended student must be afforded certain due-process protections. Specifically, the Court ruled that for short-term suspensions a student must receive (a) oral or written notice of the charges, (b) an explanation of the charges and evidence supporting them, and (c) an opportunity to present his or her side of the story. Generally, the notice and hearing requirements should precede the removal of a student from school. In emergency situations, however, the student may be removed from school immediately, but the necessary notice and hearing should follow as soon as possible.

The Supreme Court also noted that suspensions or expulsions in excess of 10 school days might require more extensive due-process procedures. More extensive procedures might include written notice of the hearing and evidence against a student and a formal hearing in which a student could introduce evidence, face his or her accusers, present witnesses, be represented by a lawyer, and appeal the suspension or expulsion decision to a state education agency.

The due-process protections outlined in Goss, must be extended to all students who face suspensions. This includes students with disabilities. In fact, IDEA ' 97 does not create more rigorous procedural protections for students with disabilities than the minimal protections in Goss (Gorn, 1999). If a suspension of a student with a disability exceeds 10 consecutive school days or amounts to a change in placement, however, the procedural protections of the IDEA apply.

These due process protections will not shield students from properly imposed suspensions. Rather, the purpose of the protections is to protect students from an unfair or mistaken suspension. The protections that must be afforded to students who are suspended are limited by the school's interest in maintaining order and discipline.

\section{Ensuring That Discipline Practices Are Nondiscriminatory}

All students with mental or physical impairments that affect a major life function are protected from discrimination under Section 504 of the Rehabilitation Act of 1973 (hereafter, Section 504). This includes students with disabilities who are not covered by the IDEA and students in special education who are covered. Discrimination refers to unequal treatment of qualified students with disabilities based solely on the basis of the disability.
School districts violate Section 504 in four primary ways when disciplining students with disabilities.

1. Disciplining students with disabilities by using procedures that are not used with nondisabled students who exhibit similar misbehavior

2. Disciplining students with disabilities by using procedures that are harsher than those used with nondisabled students who exhibit similar misbehavior

3. Suspending (long-term), expelling, or changing the placement of a student with disabilities for misbehavior that is related to the student's disability

4. Disciplining a student using procedures that are prohibited in the IEP or behavior plan.

To ensure that discipline is not applied in a discriminatory manner, and thus in violation of Section 504, schools officials should adopt the following procedures (Gorn, 1999):

1. When appropriate, schools must use the same disciplinary procedures for students with and without disabilities. In such situations, IEP teams or Section 504 teams should include the schools' regular disciplinary policy in a student's IEP or Section 504 accommodation plan.

2. As required by IDEA '97, schools must conduct manifestation determinations to assess the relationship between a student's disability and misconduct before instituting long-term suspensions, expulsions, or changes in placements (see the section on manifestation determinations).

3. Administrators must ensure that all school officials and the student's teachers understand the contents of the IEP, BIP, or Section 504 plans and follow the interventions and disciplinary procedures contained in these documents. Discipline plans that are written into IEPs or Section 504 plans preempt a school district's regular disciplinary code.

\section{IDEA'97 AND DISCIPLINE}

In the IDEA '97, Congress addressed a number of issues related to discipline. In addition, the final regulations to IDEA ' 97 further clarified the law's discipline provisions. According to the Office of Special Education Programs (OSEP) of the Department of Education (Senate Report, 1997), the goals of the disciplinary provisions of IDEA ' 97 were that:

1. All students, including students with disabilities, deserve safe, well-disciplined schools and orderly learning environments;

2. Teachers and school administrators should have the tools they need to assist them in preventing misconduct 
and discipline problems and to address those problems, if they arise;

3. There must be a balanced approach to the issue of discipline of students with disabilities that reflects the need for orderly and safe schools and the need to protect the right of students with disabilities to a free appropriate public education (FAPE); and

4. Students have the right to an appropriately developed IEP with well designed behavior intervention strategies.

In IDEA ' 97 , Congress sought to expand the authority of school officials to protect the safety of all children by maintaining an orderly, drug-free, and disciplined school environment while ensuring that the essential rights and protections for students with disabilities were protected (Office of Special Education Programs, 1999). In writing the discipline provisions, Congress sought to help school officials and IEP teams to (a) respond appropriately when students with disabilities exhibit serious problem behavior, and (b) appropriately address problem behavior in the IEP process. Whether they succeeded in this effort will be evident in public schools' ability to carry out the disciplinary provisions of IDEA '97 (Yell et al., 2000).

School personnel must be aware of the law and regulations and able to effectively implement their provisions. Three major points underlie the disciplinary changes of IDEA '97. First, the law emphasizes the use of positive behavioral interventions, supports, and services for students with disabilities who exhibit problem behaviors. The purpose of positive programming is to teach appropriate behaviors that increase the likelihood of a student's success in school and in post-school life, rather than merely using punishment-based programming to eliminate inappropriate behavior. These procedures must be included in students' IEPs when appropriate.

Second, school officials may discipline a student with disabilities in the same manner as they discipline students without disabilities, with a few exceptions. A school's regular disciplinary procedures can be used with students with IEPs as long as they (a) are used with nondisabled students and students with disabilities (i.e., the procedures are not discriminatory), (b) do not result in a unilateral change in a student's placement (i.e., suspension in excess of 10 cumulative school days that constitutes a pattern of exclusion, change of educational placement made by school personnel and not the IEP team, and expulsion from school) and (c) do not result in the cessation of educational services.

Third, discipline should be addressed through the IEP process. Yell et al. (2000) predicted that school districts are most likely to violate the disciplinary provisions of IDEA '97 by (a) failing to address problem behavior and discipline in the IEP process and (b) not following the behavioral plans and disciplinary procedures indicated in a student's IEP and IDEA '97 (e.g., a principal unilaterally expels a student with disabilities rather than adhering to the discipline plan in the IEP).

Moreover, if school personnel and parents can arrive at solutions to a student's discipline problems through the IEP process (e.g., changing a student's placement to an alternative school rather than moving to expel him or her), there is no need to invoke the disciplinary provisions of IDEA ' 97. We next provide analysis and commentary on the discipline sections of IDEA '97 that we believe will have the greatest impact on school officials.

\section{ADDRESSING PROBLEM BEHAVIOR IN THE IEP PROCESS}

IDEA 97 requires that if a student with disabilities exhibits problem behaviors that impede his or her learning or the learning of others, the student's IEP team shall consider "strategies, including positive behavioral interventions, strategies, and supports to address that behavior" (IDEA, 20 U.S.C. $§ 1414$ (d)(3)(B)(i)). Comments to the federal regulations indicate that if a student has a history of problem behavior, or if such behaviors can be readily anticipated, the student's IEP must address that behavior (IDEA Regulations, 34 C.F.R. $\S 300$ Appendix A, question 39). This requirement applies to all students in special education, regardless of their category of disability.

Neither IDEA '97 nor the regulations indicates what these behaviors are. The lack of specificity is consistent with the IDEA's philosophy of allowing IEP teams to make individualized decisions for each student (Gorn, 1999). The IEP team, therefore, has to determine which behaviors are significant enough to require interventions formally written into the IEP. From previous hearings and court cases, Drasgow, Yell, Bradley, and Shriner (1999) inferred that these problem behaviors may include (a) disruptive behaviors that distract teachers from teaching and students from learning, (b) noncompliance, (c) verbal and physical abuse, (d) property destruction, and (e) aggression toward students or staff.

These problem behaviors should be addressed in the following manner.

1. When a student exhibits problem behavior, the IEP team must determine if the behavior impedes his or her learning or other students' learning.

2. If the team decides that the problem behavior does interfere with the student's learning, it must conduct an assessment of the behavior.

3. The IEP team must develop a plan based on the information gained from the assessment that reduces problem behaviors and increases socially acceptable behaviors. 
Results of the team's decisions must be included in the IEP. This means that the IEP of a student with serious problem behaviors must include the information from the assessment in the "present levels of performance" section of the IEP. Because educational needs must be addressed by developing appropriate special education programming, the IEP also must include (a) measurable goals and objectives, and (b) special education and related services that address the problem behavior. Moreover, if the student's behavioral program involves modifications to the general education classroom, these modifications must be included in the IEP. When an IEP team addresses a student's problem behavior, the needs of the individual student are of paramount importance in determining the behavior strategies appropriate for inclusion in the child's IEP (OSEP Questions and Answers, 1999).

If an IEP team fails to address a student's problem behaviors in the IEP, that failure would deprive the student of a free and appropriate public education (Drasgow et al. 1999). This could result in application of the law's sanctions against the school district. To underscore the importance of including positive programming that addresses significant problem behavior in students' IEPs, Thomas Hehir, former director of the U.S. Department of Education's Office of Special Education Programs stated that "the key provision in IDEA '97 is using positive behavioral interventions and supports" (Office of Special Education Programs, 1999, p. 707) in the IEPs of students who exhibit significant problem behaviors. Failure to do so "would constitute a denial of the free appropriate public education (mandate of the IDEA)" (IDEA Regulations, Appendix B, Question 38).

IDEA ' 97 encourages, and sometimes demands, that IEP teams address problem behaviors by conducting functional behavioral assessments (FBAs) and by developing education programming based on the results of the assessment (Drasgow \& Yell, in press). In the following section we examine the law's requirements regarding FBAs.

\section{Functional Behavioral Assessment}

An FBA is a process that searches for an explanation of the purpose behind a problem behavior (OSEP Questions and Answers, 1999). Although the U.S. Department of Education has not defined an FBA, it is reasonable to assume that Congress intended that the term be consistent with the meaning in the professional literature (Drasgow et al., 1999; Gorn, 1999). FBA is a process to gather information about factors that reliably predict and maintain problem behavior in order to develop more effective intervention plans (Horner \& Carr, 1997; O'Neill et al., 1997). In essence, an FBA is used to develop an understanding of the cause and purpose of problem behavior (Drasgow et al., 1999).
The law intends that an FBA should be part of the process of addressing problem behavior. Moreover, the purpose of an FBA, or any special education assessment, is not merely to determine eligibility. Rather, its purpose is to determine the educational needs of students with disabilities and then to develop effective programming to meet those needs.

IDEA '97 does not detail the components of an FBA. Neither did the U.S. Department of Education include additional information on FBAs in the final regulations. This means that the composition of FBAs will be left to states, school districts, and IEP teams. According to OSEP, a definition was not offered in the IDEA '97 regulations because IEP teams have to "be able to address the various situational, environmental, and behavioral circumstances raised in individual cases" (Analysis of Comments and Changes, 1999). The decision to conduct an FBA, therefore, is left up to the professional judgment of the IEP team. Nonetheless, an IEP team must conduct an FBA in certain situations-when a student in special education is suspended for more than 10 days or placed in an interim alternative educational setting (IAES).

\section{Functional Behavioral Assessments and Suspension}

IDEA ' 97 requires that the IEP team must meet and conduct or revise an FBA and BIP within 10 business days from when a student is (a) first removed for more than 10 school days in a school year, (b) removed in a manner that constitutes a change in placement, or (c) placed in an IAES for a weapons or a drug offense. In these situations, the IEP team must convene to conduct an FBA and develop a BIP. Martin (1999) suggests, however, that IEP teams should conduct an FBA if a student is approaching 10 cumulative days of suspension rather than waiting until the 10-day limit has been reached.

For subsequent removals of a student who already has an FBA and a BIP, the IEP team members can individually review the BIP and its implementation. The review of the student's behavior may take place without a meeting unless one or more of the team members believe that the plan (or its implementation) requires modification (IDEA Regulations, 34 C.F.R. $\$ 300.520(\mathrm{c})$ ).

The regulations did not intend that school personnel develop behavioral interventions within 10 days of removing a student from the current placement. Instead, the regulations are intended to require that public schools expeditiously conduct the FBA. Moreover, the regulations ensure that the IEP team develops appropriate behavioral interventions based on the assessment. Those interventions then must be implemented as quickly as possible.

The purpose of conducting an FBA is to develop educational programming related to the cause and purpose of the problem behaviors. IDEA '97 refers to specific programming 
to address problem behavior as a BIP. In the next section we review IDEA '97's requirements with respect to BIPs.

\section{Behavior Intervention Plans}

The IEP team develops a BIP based on the FBA. As was the case with FBAs, IDEA 97 does not provide details about the composition of the BIP beyond indicating that the plan has to be individualized to meet the needs of different students in different educational environments. The U.S. Department of Education also refused to define a BIP. Congress and the Department of Education apparently expected that the term "behavioral intervention plan" would have a commonly understood meaning in the special education field (Gorn, 1999).

Behavior intervention plans have to be proactive and multidimensional. This means that IEP teams should implement multiple BIP strategies aimed at preventing problem behavior before it becomes severe enough to warrant sanctions such as suspension or expulsion (Drasgow et al., 1999; Gorn, 1999; Yell et al., 2000). In fact, behavioral plans that merely describe acts of prohibited misconduct and then specific consequences for misbehavior are almost certainly illegal because they are reactive instead of proactive (Gorn, 1999).

The BIP is a behavior-change program emphasizing multiple strategies that include teaching prosocial behaviors. The key component of the BIP is the use of multiple positive behavioral interventions that do not rely on coercion or punishment for behavior change (Dunlap \& Koegel, 1999). Figure 1 lists important considerations when conducting FBAs and developing BIPs.

Despite the presence of positive behavioral intervention and support plans, Congress recognized that school officials still needed clarification of which disciplinary procedures could be used when students with disabilities exhibit serious misbehavior. Most discipline procedures used with students in public schools are permitted under IDEA '97 (e.g., time-out, in-school suspension). When the student misconduct is serious enough to warrant suspension or expulsion, however, the strictures of IDEA '97 must be followed. In the following section we discuss IDEA '97's requirements regarding short-term and long-term disciplinary removals.

\section{SHORT-TERM DISCIPLINARY REMOVALS}

IDEA ' 97 authorizes school officials (i.e., building-level administrators) to unilaterally suspend students with disabilities, or to place students in an alternative educational program on a short-term basis, to the same extent that such suspensions or removals are used with students without disabilities. According to the U. S. Department of Education, the reason that school officials may make such decisions unilaterally (i.e., acting by themselves) is that maintaining safety and order in the school sometimes requires that students with disabilities be removed from the school environment immediately (Office of Special Education Programs, 1999).

To react quickly to such situations, the building-level administrator can remove a student with disabilities from school without having to convene an IEP team, conduct a manifestation determination, or seek permission to do so from a student's parents. School officials, however, must inform a student of his or her due process rights (i.e., oral or written notice of the charges, an explanation of the evidence that supports the charges, and an opportunity to present his or her side of the story).

\section{How Many Days of Suspension Are Allowed?}

IDEA '97 does not establish a specific limitation on the number of days in a school year that students with disabilities can be suspended from school. As a result of this lack of information in the statute and regulations, a great deal of confusion surrounds the number of days that students with disabilities can be suspended without violating the IDEA.

\section{Functional Behavioral Assessment (FBA)}

Did the IEP team define the target behavior in measurable terms when conducting the FBA?

Did the IEP team consider the contextual factors that might contribute to the behavior?

Did the IEP team determine the intent of the behavior?

\section{Behavior Intervention Plan (BIP)}

Did the IEP team attempt to reduce future occurrence of the target behavior when developing the BIP?

Did the IEP team make contextual modifications to reduce the inappropriate behavior?

Did the IEP team identify an appropriate replacement behavior? 
Students with disabilities may be removed from school for up to 10 cumulative or consecutive school days, as long as the suspensions are used with nondisabled students as well.

School officials must keep two critical points in mind when using short-term suspensions. First, the upper limit on out-of-school suspensions is 10 consecutive days. If a suspension exceeds this limit, it becomes a change of placement. In this situation, if school officials do not follow the IDEA's change of placement procedures (e.g., written notice to the student's parents, convening the IEP team), the suspension is a violation of the law (see the discussion on change of placement procedures for an explanation of this area of the law). Second, when the total number of days that a student has been suspended is more than 10 cumulative days in a school year, educational services must be provided.

\section{When Should Educational Services Be Provided To Suspended Students?}

Educational services must be provided after the 10th cumulative day of removal. For example, if a student is suspended for 10 cumulative days in the fall semester, and then is suspended for 3 more days in the spring term, educational services must be provided from the first day in which cumulative suspensions exceed 10 days or, in this case, the first day of suspension in the spring. Therefore, school officials may implement additional short-term suspensions for separate incidents of misconduct, as long as they provide educational services to the suspended student.

Although not directly addressed in IDEA '97, if a student is suspended for fewer than 10 school days, a school district is not required to continue educational services (IDEA Regulations, 34 C.F.R. $§ 300.121(d)(1))$. School officials, in consultation with the student's special education teacher, should determine the content of the educational services, if the suspensions equal fewer than 10 cumulative days. When suspensions amount to more than 10 cumulative days, the IEP team must determine educational services. The educational services provided to students must allow them to (a) progress in the general education curriculum, (b) receive special education and related services, and (c) advance toward achieving their IEP goals.

Because there are limits on the number of days in which a student with disabilities may be removed from the school setting, school officials should use out-of-school suspensions judiciously and in emergency situations. Moreover, school personnel should keep thorough records of the number of days in which students with disabilities are removed from schools for disciplinary reasons so they do not inadvertently violate the provisions of IDEA ' 97 . In addition, Gorn (1999) suggests that the school district should describe the student's misconduct that led to the long-term suspension, the start date and duration of the proposed suspension, and a description of other disciplinary sanctions that school officials considered and rejected.

The frequency and number of short-term removals, if they are excessive, could indicate a defective IEP. Martin (1999) asserts that the more short-term disciplinary removals, the greater is the likelihood that a hearing officer will find that the behavior portion of the IEP is inappropriate and a deprivation of the student's right to an FAPE. Indeed, if a student is approaching 10 cumulative days of suspension, the IEP team should be convened to review the student's behavioral plans, conduct a functional behavioral assessment, and develop or review the student's BIP. Martin (1999) also suggests that the IEP team should conduct a manifestation determination prior to the 11th day of accumulated short-term removals. Figure 2 is a checklist depicting important considerations when using short-term disciplinary removals.

\section{LONG-TERM DISCIPLINARY REMOVALS}

As mentioned previously, IDEA '97 did not establish a specific limitation on the number of days in a school year

\section{School Administrators}

Did you provide oral or written notice of the charges against the student?

If the student denied the charges, did you provide an explanation of the evidence supporting the charges? Did you offer an opportunity for the student to present his or her side of the story?

\section{The IEP Team}

Did the team convene prior to the 11 th day of removal?

Did the team develop a plan for conducting the functional behavioral assessment (FBA)?

Did the team develop or review the behavior intervention plan (BIP)?

Did the team develop a plan to ensure that the student continues to receive an FAPE? 
that students with disabilities can be suspended from school for disciplinary reasons. Thus, IDEA '97 offers no clear answer with respect to the number of days a student can be suspended before schools use long-term rather than shortterm suspensions. Nor is there an absolute limit on the number of school days that students with disabilities can be removed from their current placement in a school year (OSEP Questions and Answers, 1999). A suspension of students in excess of 10 consecutive days, however, is generally considered a long-term suspension (Gorn, 1999; Yell et al., 2000). Suspensions of this duration require that the suspended student receive appropriate educational services.

Furthermore, the IEP team must be convened to conduct an FBA, develop or revise a BIP, and conduct a manifestation determination. If the misconduct was related to a student's disability, he or she cannot be suspended more than 10 consecutive days. If the misconduct was not related to a student's disability, he or she may be suspended for more than 10 consecutive days. Of course, the district must continue to provide educational services to the suspended student, and his or her parents can challenge the decision of no relationship (see the discussion on manifestation determination). Figure 3 is a checklist that depicts important considerations when using long-term disciplinary removals.

\section{When Does a Suspension Become an Illegal Change of Placement?}

A long-term suspension-a suspension that lasts more than 10 consecutive days - is a change of placement under IDEA '97. Because such a suspension is a change of placement, the school district must follow IDEA's change of placement procedures. This means that a school district must provide the parents of the suspended student with written notice prior to initiating the change. The purpose of the notice is to give the parents an opportunity to object if they disagree with the placement change. The written notice should include an explanation of the applicable procedural safeguards (OSEP Questions and Answers, 1999).

If a student's parents object to the change of placement, the school district may not suspend the students beyond the 10 consecutive days. The only exception to this rule is when the IEP conducts a manifestation determination and decides that the students' misconduct is not related to his or her disability (the manifestation determination is discussed later in this article).

A series of short-term suspensions also may become a change in placement. The question of when disciplinary removals amount to a change of placement, however, can be determined only by a student's IEP team. To determine if a series of short-term suspensions have become a change in placement, an IEP team must determine the circumstances surrounding the suspension, including (a) the length of each removal, (b) the total amount of time the student is removed, and (c) the proximity of the removals to one another (IDEA Regulations, §300.520, Note 1). Nevertheless, neither IDEA '97 nor the regulations provide clear guidance as to when repeated short-term suspensions of fewer than 10 school days amount to a change of placement.

Ultimately, due process hearing officers and judges will answer this question. The decision to classify a series of suspensions as a change in placement can be decided only on a case-by-case basis. Therefore, when a series of short-term suspensions amount to more than 10 cumulative school days, the IEP team must be convened to determine whether these suspensions could constitute a change in placement.

Removing a student for fewer than 10 cumulative or 10 consecutive school days probably will not amount to a change in placement. Similarly, if a series of short-term suspensions of not more than 10 days each are considered separate incidences of misbehavior, there probably will not be a change of placement, as long as the suspensions do not create a pattern of exclusions. School officials, however,

\section{School Administrators}

Did you provide oral or written notice of the charges against the student?

If the student denied the charges, did you provide an explanation of the evidence supporting the charges?

Did you offer an opportunity for the student to present his or her side of the story?

Did you notify the student's parents of their procedural rights under the IDEA?

\section{The IEP Team}

Did the team develop a plan for conducting the functional behavioral assessment (FBA)?

Did the team develop or review the behavior intervention plan (BIP)?

$\square$ Did the team develop a plan to ensure that the student continues to receive a FAPE?

Did the team conduct a manifestation determination?

Did the team determine an appropriate IAES? 
must not assess repeated short-term suspensions as a means of avoiding the change of placement procedures that are required when using long-term suspensions.

According to Gorn (1999), subterfuge of this nature, if detected, invariably will result in a finding that a school district violated the procedural requirements of the IDEA. Gorn reviewed decisions from the U. S. Department of Education's Office of Civil Rights (OCR) regarding when accumulated short-term suspensions become a change of placement. She listed eight decisions from 1990 to 1997 in which OCR decided that multiple suspensions leading to between 13 and 31 days of removal were significant changes of placement and, thus, violated the law.

The OCR, however, also decided that a district's removal of a student on two separate occasions resulting in a total of 15 days of removal, and another district's removal of a student on five separate occasions for a total of 38 days of removal, did not result in a change of placement. It should be noted that OCR decisions address only violations of Section 504 and not of the IDEA. Nonetheless, because the rules regarding disciplinary removals are similar under Section 504 and IDEA '97, these decisions are useful indicators of when multiple suspensions may become a change of placement.

Finally, readers are cautioned that state law regarding suspension of students with disabilities should be consulted because some states put a ceiling on the number of days that students with disabilities can be suspended during a school year. If state law allows fewer days of suspension than does IDEA ' 97 , school officials must adhere to the state guidelines.

\section{What Can Be Done When Students Commit Weapon and Drug Offenses?}

School officials may unilaterally exclude a student with disabilities from school for up to 45 days if (a) the student brings, possesses, or acquires a weapon at school or at a school function (e.g., school dances, class trips, extracurricular activities), or (b) knowingly possesses, uses, or sells illegal drugs, or sells a controlled substance at school or a school function (IDEA, 20 USC $\S 1415(\mathrm{k})(1)$ ). A weapon is defined as a "weapon, device, instrument, material, or substance ... that is used for, or is readily capable of, causing death or serious bodily injury" (IDEA, 20 U.S.C. § $615(\mathrm{k})(10)(\mathrm{D})$ ). (For a list of weapons covered under the IDEA, see the Federal Criminal Code, 18 U.S.C. $\S 930(\mathrm{~g})$ ).

A controlled substance refers to a legally prescribed medication (e.g., Ritalin) that is illegally sold by a student. (For a list of controlled substances covered by the IDEA, see the Controlled Substances Act, 21 U.S.C. § 812(c)). Students can be removed for up to 45 days for weapons or drug offenses even when the misbehavior is related to the student's disability. In the event of such exclusions, students must be placed in an appropriate IAES.

\section{Can Schools Remove Students When They Present A Danger to Themselves or Others?}

Until the passage of IDEA '97, school districts had to seek a temporary restraining order from a court to remove a student with disabilities who presented a danger to himself, herself or others. The IDEA now authorizes school officials to seek temporary removal of a dangerous student by requesting that an impartial hearing officer order the student removed to an IAES for 45 days (IDEA 20 U.S.C. $§ 1415$ $(k)(2))$. Therefore, if school officials believe that a student might present a danger to self or others, and seek to have the student removed from school, they must convince a hearing officer that (a) if the student remains in the current placement, he or she is substantially likely to injure himself, herself, or others, (b) the school district has attempted to minimize the risk of harm, (c) the student's current IEP and placement were appropriate, and (d) the school's IAES is appropriate. The hearing officer then may change the student's placement to the IAES for up to 45 days. During this time period, the IEP team should meet to determine what actions to take (e.g., change placement, rewrite the IEP, move to expel the student).

School officials also may use long-term disciplinary removals when a student's misbehavior is not related to his or her disability, as long as the removals are equivalent to the removals that a nondisabled student would receive for a similar offense. Of course, whenever a student with disabilities is removed from school for over 10 cumulative days, even if there is no relationship between the disability and misconduct, educational services must be continued.

\section{MANIFESTATION DETERMINATIONS}

When a school district proposes a disciplinary action that could result in a change of placement (e.g., long-term suspension, expulsion), a manifestation determination must be conducted. A manifestation determination is a review of the relationship between a student's disability and misconduct. A school can use long-term suspension or expulsion only if it finds that the misconduct that led to the disciplinary removal was not related to the student's disability.

The manifestation determination must be conducted when school officials seek a change of placement, including suspension or expulsion, in excess of 10 school days. In addition, in situations in which a student has been suspended more than 10 days, the review should take place no later than 10 days following the disciplinary action.

A manifestation determination is not required for disciplinary removals of 10 or fewer days (IDEA Regulations, 34 C.F.R. $\$ 300.523(a))$. School personnel will not have to conduct a manifestation determination, therefore, unless they 
decide to remove a student from school via disciplinary long-term suspension or exclusion.

\section{How Should an IEP Team Conduct a Manifestation Determination?}

A student's IEP team and other qualified personnel must conduct the manifestation determination. It is important that the team that conducts the manifestation hearing include all the members required to be on an IEP team (i.e., a student's parents, special education teacher, general education teacher, LEA representative, a person who can interpret instruction implications of the evaluation). In fact, a manifestation determination conducted without all the members of the IEP team present was overturned in Searcy Public Schools (1998). Thus, the IEP team must be convened immediately when school officials decide to (a) suspend a student more than 10 consecutive days, (b) suspend a student for a short period, if suspensions of the student have accumulated to the extent that a pattern of exclusions, and possibly a change of placement, have occurred, or (c) expel a student. If a placement is not appropriate for a student, and a change of placement is made through the IEP process, a manifestation determination is not necessary.

Three distinct steps should be followed when conducting the review. First, the IEP team must gather all relevant information regarding the misbehavior, including evaluation and diagnostic results, informal assessments, direct observations, interviews, and school records. This information must be recent and up-to-date. In addition, the student's parents can supply any evaluation data they want the team to consider. The team's task is to use the data to determine if the student understood the consequences of his or her behavior and was capable of controlling it (i.e., the relationship test).

Second, the team should review a student's IEP and placement. The purpose of this step is to ensure that an inappropriate educational program did not cause the misconduct that led to the manifestation hearing. The team's task is to determine if the student's program of special education and related services and placement are appropriate, and if the IEP is being implemented as written.

If, during this stage of the manifestation determination, the IEP team finds deficiencies in a student's IEP, placement, or in implementation of the IEP, these deficiencies must be corrected immediately (IDEA Regulations, 34 C.F.R. $\S 300.523(f))$. This, of course, includes the behavioral components of an IEP (e.g., behavioral goals and objectives). Similarly, if a student has a BIP, it also should be checked for appropriateness and implementation. If the team finds that the IEP (a) did not offer the student a free appropriate public education, (b) did not adequately address the student's problem behavior, or (c) the IEP was not implemented properly, the manifestation hearing ends and the IEP team must conclude that the misbehavior was a manifestation of the student's disability (Senate Report, 1997).

The third step of the process involves reviewing the evaluation data to determine if the misbehavior was related to the student's disability. This part of the manifestation determination has been referred to as the relationship test (Hartwig \& Reusch 1995; Kubick, Bard, \&. Perry, 2000; Yell et al., 2000). The relationship test is based on an individualized analysis of a student, his or her disability, and the student's misbehavior. The relationship test must not be categorically driven. This means that it is not appropriate to make the manifestation determination based on a student's disability or categorical label (Hartwig \& Reusch 2000; Kubick, Bard, \&. Perry, 2000). Neither does the team base its decision on an analysis of whether the student knew right from wrong (Doe v. Maher, 1986).

When conducting the relationship test, the team must answer two questions:

1. Did the student's disability impair the ability of the student to understand the impact and consequences of the behavior for which he or she is being disciplined?

2. Did the student's disability impair his or her ability to control the behavior in question?

If the answer to either of these questions is yes, the manifestation determination ends and the misbehavior is considered related to, or a manifestation of, the student's disability. On the other hand, a finding of no relationship would indicate that the student was able to understand the consequences of his or her misbehavior and was capable of controlling it. If the team determines that there is no relationship between the misconduct and the disability, the same disciplinary procedures as would be used with students who are not disabled may be imposed on a student with disabilities, including long-term suspension and expulsion. Educational services, however, must be continued.

The student's parents may request an expedited due process hearing if they disagree with the results of the manifestation determination. The student's placement during the hearing will be in the IAES. Figure 4 is a checklist depicting important considerations when conducting a manifestation determination. Figure 5 is a flowchart that should be followed when conducting a manifestation determination.

\section{Who Bears the Burden of Proof in Manifestation Determinations?}

The question of which party bears the burden of proof in litigation has often been an area of conflict. Burden of proof means that, when parties, in taking a given position, have to 


\section{School Administrators}

Did you notify the student's parents of their procedural rights under the IDEA no later than the date on which the disciplinary action was recommended?

\section{The IEP Team}

Did the team convene within 10 days after the decision to discipline the student?

Did the team gather all relevant data, including evaluation and diagnostic results (e.g., information from the student's parents, observations, interviews, the student's IEP, and placement information)?

Did the team determine that, in relationship to the behavior subject to the disciplinary action, the student's IEP and placement were appropriate?

Did the team determine that the special education services, supplementary aids and services, and behavior intervention strategies were consistent with the student's IEP and placement?

Did the team ensure that the student's disability did not impair his or her ability to understand the impact and consequences of the behavior subject to the disciplinary action?

Did the team ensure that the student's disability did not impair the student's ability to control the behavior subject to the disciplinary action?

\section{FIGURE 4}

\section{Administrator and IEP Team Checklists for the Manifestation Determination and Hearing}

prove the correctness of their position to the satisfaction of a hearing officer or a judge (Yell, 1998). If school personnel make a decision that the behavior and the disability have no relationship, and expel a student, the burden of proof will be placed on the school district to prove that there is no relationship.

The regulations implementing IDEA '97 require that

in reviewing a decision with respect to the manifestation determination, the hearing officer shall determine whether the public agency has demonstrated that the child's behavior was not a manifestation of the child's disability consistent with the requirements of [the law]" (IDEA, 20 U.S.C. $\S$ 1415(k)(B)(i).

The burden of proof requirement in IDEA '97 requires that hearing officers and judges closely scrutinize the decision-making process followed during the manifestation determination.

\section{INTERIM ALTERNATIVE EDUCATIONAL SETTINGS}

IDEA '97 requires that an FAPE must be made available to all eligible students with disabilities, even those who have been suspended or expelled from school (IDEA, 20 U.S.C.
$\S 1412$ (a)(1)). According to the regulations (IDEA Regulations, 34 C.F.R. $\$ 300.520(a)(1)(i i)$ ) and Department of Education guidance (OSEP Questions and Answers, 1999) when a student is suspended in excess of 10 cumulative days during a school year, the school district must continue to provide an FAPE. This means that on the 11th cumulative day of a student's removal from school, educational services must begin. These services are provided in an IAES (IDEA, 20 U.S.C. $\S 1415(\mathrm{k})(3))$.

\section{When Should an IAES Be Used for Disciplinary Purposes?}

IDEA '97 describes three specific circumstances when an IAES may be used for disciplinary purposes. First, an IAES may be used for a short-term disciplinary removal from school for 10 or fewer days. School officials may unilaterally impose a short-term suspension on a student with a disability for fewer than 10 consecutive days for violating school rules and for additional removals for not more than 10 consecutive days in a school year for separate incidents of misconduct, as long as these removals do not constitute a change in placement. After 10 days of removal in a school year, educational services must be provided to suspended children. 


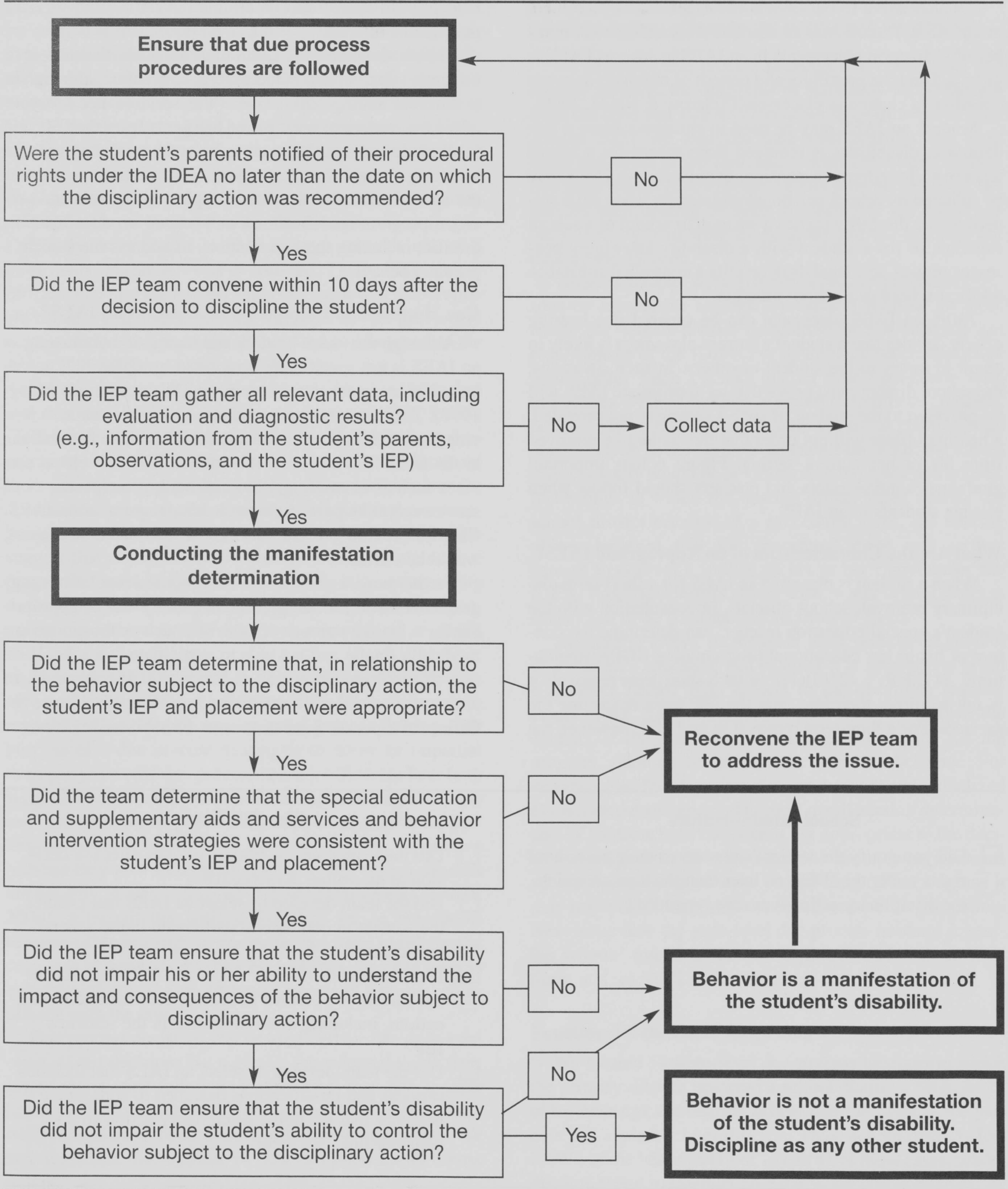


An alternative to out-of-school suspension is placement in an IAES. There is not an absolute limit on the total number of short-term placements in an IAES as long as FAPE is provided and the proximity and pattern of removals does not constitute a change in placement (Telzrow \& Naidu, 2000).

Second, an IAES may be used in situations when a student with disabilities is removed from school for a longer term (e.g., long-term suspension, expulsion). An IAES may be initiated by school personnel unilaterally when (a) a student with a disability carries a weapon to school or a school function, or (b) a student with a disability knowingly possesses or uses an illegal drug or sells a controlled substance while at school or a school function.

Third, an IAES placement can be ordered if a hearing officer decides that a student's current placement is likely to result in injury to the student or others. In such situations, the school district must prove that an appropriate IAES will be provided to the student. If such a setting is not provided, a hearing officer will not order that the student be removed from his or her current setting. Figure 6 lists important guidelines administrators and teachers should follow when placing students in an IAES.

\section{What Are the Characteristics of an Appropriate IAES?}

When a student is placed in an IAES for a short-term disciplinary removal, school officials, in consultation with the student's special education teacher, can determine the content of his or her educational programming (IDEA Regulations, 34 C.F.R. $\$ 121(3)(1))$. In such short-term removals it is not required, therefore, that the IEP team determine the services. For a long-term removal in an IAES, however, the student's IEP team must determine the setting and services that will be offered.

In both situations, the IAES must (a) allow the student to continue to participate in the general curriculum, although in a different setting, (b) provide the services necessary to allow the student to meet his or her goals from the IEP, and (c) include services designed to keep the misbehavior from recurring. In addition, the school must continue to receive the special education services, supplementary aids and services, program modifications, and related services listed in the IEP, including the interventions to address the student's problem behavior.

\section{Can Homebound Placements Be Used for an IAES?}

Although the use of homebound instruction or tutoring as an IAES is not specifically prohibited by IDEA '97, homebound placements are problematic (Katsiyannis \& Maag, 1998). This is because school districts must continue to provide the services listed in a student's IEP while he or she is in the IAES. For example, if a student receives related services such as counseling, physical therapy, or speech, these services must be part of the student's program in the IAES. Clearly, providing these services in a homebound setting would be difficult.

Furthermore, a comment in the proposed regulations suggests that a homebound placement usually will be appropriate for a limited number of students, such as those who are medically fragile and not able to participate in a school setting (IDEA Regulations, 34 C.F.R. $\$ 300.551$, Note 1). In answers to a series of questions regarding discipline, the Office of Special Education and Rehabilitative Services

\section{School Administrators}

Did you notify the student's parents of their procedural rights under the IDEA no later than the date on which the disciplinary action was recommended?

\section{The IEP Team}

Did the team convene within 10 days after the decision to discipline the student?

Did the team develop or select an IAES that enables the student to continue to participate in the general curriculum?

Did the team develop or select an IAES that enables the student to continue to receive services and modifications, including those described in the student's IEP?

Did the team develop or select an IAES that includes services and modifications designed to address the behavior that led to the disciplinary action so the behavior does not recur? 
(OSERS) noted that, in most circumstances, homebound instruction is inappropriate as a disciplinary measure; however, the final decision regarding placement must be determined on a case-by-case basis (Department of Education Answers Questions, 1997). In hearings, it will be up to school districts to justify homebound placements (Gorn, 1999). If districts have in-school suspension programs or alternative schools and instead opt for placing a student in a homebound setting, it may be difficult to justify to a hearing officer the use of the more restrictive homebound setting.

Finally, in one state-level hearing, a school's use of a homebound placement was overturned. The hearing review officer ruled that the homebound placement was inappropriate because it failed to provide the services that previously were included in a student's IEP (Board of Education of the Akron Central School District, 1998).

For short-term IAES placements, schools should develop and use in-school suspension programs as their IAESs (Telzrow \& Naidu, 2000). Advantages of using these programs for an IAES are that students continue to work on their individualized goals and objectives and receive the special education, related services, and behavioral programming required by their IEPs (Yell, 1998). Those authors also suggest that school districts consider the use of alternative programs or schools for long-term IAES placements as long as these programs include the academic and behavioral programming and parental involvement required in a student's IEP.

The procedural safeguards of the IDEA allow parents who wish to contest a school's special education decisions regarding their child to request a due process hearing. The purpose of a due process hearing is to allow an impartial third party (i.e., the due process hearing officer) to hear both sides of a dispute, examine the issues in relation to the law, and then settle the dispute by imposing a solution on the parties involved. Due process hearings can be instructive because they give an indication of how well school districts are actually implementing the IDEA's requirements (Smith, 2000). Although due process hearings set no precedents because other hearings or courts do not have to follow the decisions of previous due process hearings, they can give us valuable information about trends in school districts' compliance with the law.

Due process decisions can be appealed to state or federal court. Court decisions have greater precedential value (i.e., lower courts must follow their decisions) than due process hearings. Because IDEA '97 was passed only recently, not many cases have been filed dealing with discipline. We anticipate that that number of hearings appealed to courts will increase during the next few years. In the following sections, we review hearings that have involved the discipline provisions of IDEA ' 97.

\section{HEARING DECISIONS ON DISCIPLINING STUDENTS WITH DISABILITIES}

We reviewed due process hearings and court cases that directly involved the discipline of students with disabilities from the time that IDEA '97 became law-June 1997 until August 2000. We analyzed state-level hearings and court cases published in the Individuals with Disabilities Education Law Report (IDELR) during this time period. We categorized each hearing decision according to the prevailing party (i.e., by who won the hearing) and the rationale for making the decision.

These rationales were grouped as either procedural reasons or substantive reasons. Procedural reasons involved errors the school district committed in not carrying out requirements of the IDEA. For example, a procedural error would occur when a school district expels a students with disabilities without holding a manifestation determination, because the IDEA clearly requires that a manifestation determination be held prior to an expulsion. Thus, the school district clearly would be in violation of the law's procedures. In hearings in which the hearing officer ruled against the school district because of a procedural error, the hearing officer believed that the procedural error was serious enough to deprive a student of his or her rights under the IDEA. Procedural errors occur, then, when school districts simply fail to do what the law requires of them.

Substantive errors, on the other hand, refer to the content of a student's education and whether it is appropriate given a student's needs. With respect to the discipline requirements of the IDEA, substantive errors usually involve the conduct of the evaluation of a student's behavior and the program planning to address the problem behavior. For example, the IEP team must collect recent individualized evaluation data when conducting a manifestation determination. If the team used data that is not appropriate to the decision-making process, or is outdated, that may be a serious substantive error in the eyes of a hearing officer because it may result in an inappropriate manifestation determination. Next we review the state-level due process hearings regarding schools' use of (a) FBAs, (b) manifestation determinations, and (c) IAES placements.

\section{Functional Behavioral Assessments}

We located 14 state-level due-process hearings in which the primary dispute involved a school district's FBA. In 13 of the hearings, the hearing officer ruled in favor of the parents and against school districts. Thus, school districts lost in $94 \%$ of the hearings ( 13 of 14). In 11 of these cases, school districts failed to conduct an FBA when it was required by IDEA ' 97 . In three of the hearings, school districts conducted an inadequate FBA. Table 1 depicts the procedural 


\section{Table 1}

\section{Reasons for School District Losses in Hearings on Functional Behavioral Assessments}

\begin{tabular}{|c|c|}
\hline Procedural & Substantive \\
\hline $\begin{array}{l}\text { - No FBA was } \\
\text { conducted when } \\
\text { one was required } \\
\text { by the IDEA } \\
\text { - An FBA was not } \\
\text { completed in a } \\
\text { timely manner }\end{array}$ & $\begin{array}{l}\text { - The FBA was inadequate (a one-hour } \\
\text { observation) and, therefore, resulted } \\
\text { in a denial of an FAPE } \\
\text { - Even though a student exhibited } \\
\text { serious problem behavior the IEP did } \\
\text { not conduct an assessment nor did } \\
\text { they address behavior in the student's } \\
\text { IEP }\end{array}$ \\
\hline
\end{tabular}

and substantive errors made by the losing parties in these hearings.

These results indicate that the primary difficulty that school districts face is complying with the procedural requirements of the law when disciplining students with disabilities (Drasgow \& Yell, in press). School districts still seem to be challenged by the law's requirements 3 years after the passage of IDEA '97. It is reasonable to assume that after school officials and IEP teams better understand legal requirements of the discipline sections of IDEA '97, schools will lose fewer hearings because of procedural errors. It also is likely, however, that there will be an increase in hearings and cases in which school districts lose because they did not conduct adequate FBAs. This situation is extremely likely because school districts will encounter parents in due process hearings who have hired expert witnesses to bolster their cases.

Thus, the hearing officer may be in the position of comparing a school's inadequate FBA to an independent evaluator's thorough FBA. Schools are likely to lose when the hearing officer compares an inadequate FBA to an FBA conducted in accordance with best practices.

\section{Interim Alternative Educational Settings}

We located 18 state-level due process hearings in which the primary dispute involved a school district's IAES. In 11 $(61 \%)$ of the hearings, the hearing officer ruled in favor of the parents and against school districts. Thus, the school districts prevailed in 7 (39\%) of the hearings. Table 2 depicts the procedural and substantive errors made by the losing parties in these hearings.

Legal challenges to the school district's IAES placements usually have focused on the quality of educational services provided to students in these settings. These challenges have been successful when the school districts failed to provide

\section{Table 2}

Reasons for School District Losses in Hearings on Interim Alternative Educational Settings

\begin{tabular}{|c|c|}
\hline Procedural & Substantive \\
\hline $\begin{array}{l}\text { - Administrator } \\
\text { rather than the IEP } \\
\text { team determined } \\
\text { the IAES } \\
\text { - No IAES was } \\
\text { developed when } \\
\text { one was required } \\
\text { - Failure to imple- } \\
\text { ment student's } \\
\text { IEP when he or } \\
\text { she was placed in } \\
\text { an IAES }\end{array}$ & $\begin{array}{l}\text { - School districts failed to show that a } \\
\text { student would benefit educationally in } \\
\text { an IAES } \\
\text { - The student's IAES placement did not } \\
\text { address the problem behavior } \\
\text { - The IAES did not allow access to the } \\
\text { general curriculum } \\
\text { - Rather than designing the IAES to } \\
\text { fully implement the IEP, the team } \\
\text { simply amended the IEP to remove } \\
\text { previous services } \\
\text { - The IAES did not meet all of the } \\
\text { student's educational needs } \\
\text { - The student did not work on his or her } \\
\text { IEP goals while in the IAES } \\
\text { - The educational program for the } \\
\text { student while he or she was in the IEP } \\
\text { was not defined or implemented }\end{array}$ \\
\hline
\end{tabular}

appropriate special education and related services to students while they were in an IAES, or when they did not provide appropriate behavioral planning.

Indeed, the quality of the special education services probably will prove to be the Achilles heel of many school districts' IAES placements. Martin (1999) contends that the key to school districts' successfully defending such placements will be to maintain the special education and related services that were needed to provide an FAPE, while emphasizing the new and additional aspects of the IAES that will be provided to address the student's problem behavior (e.g., behavior goals, psychological services, counseling, social skills training, additional staff assistance, parent training). Martin further asserts that most special education attorneys advise that an IAES must allow for implementation of a student's IEP, including special education instruction, modifications, related services, and behavioral programming.

\section{Manifestation Determinations}

We located 35 state-level due process hearings in which the primary dispute involved a school district's manifestation determination. In 19 (54\%) of the hearings, the hearing officer ruled in favor of the parents and against school districts. The school districts prevailed in $16(46 \%)$ of the hearings. 
Table 3 depicts the procedural and substantive errors the losing parties made in these hearings. Our findings indicate, as did Smith's (2000), that a major difficulty of many of the losing school districts in these hearings was in understanding when the manifestation determination is required. These violations were procedural.

A number of school districts, however, committed substantive violation that caused the hearing offices to overturn their decisions. For example, in a hearing held in South Carolina, Laurens County School District \# 55 (1999), the IEP team did not conduct a thorough evaluation prior to holding the manifestation hearing. Furthermore, rather than determining if the student understood the consequences of his behavior (i.e., the relationship test), the IEP team decided that the most important question was whether the student knew the difference between right and wrong.

The manifestation determination, however, is not an inquiry into whether a student knew the difference between right and wrong. According to the U.S. Court of Appeals for the Fifth Circuit in $S-1$ v. Turlington (1981), whether students are capable of understanding rules or regulations or right from wrong is not tantamount to a determination that the student's misconduct was or was not a manifestation of the disability.

These findings indicate that hearing officers will not automatically uphold a district's manifestation determination just because the procedural steps were completed correctly. The

\section{Table 3 \\ Reasons for School District Losses in Hearings on Manifestation Determinations (MD)}

\section{Procedural}

Substantive

- The school district did not conduct an MD when required to do so by IDEA
- An inappropriate evaluation was conducted prior to conducting the MD

- The IEP team did not consider all evaluation data when conducting the MD

- The entire IEP team was not convened to conduct the MD (e.g., general educator was absent)

- The IEP was not appropriate; thus, the behavior was a manifestation of the disability

- The IEP team, rather than answering the questions required in the IDEA when conducting an $\mathrm{MD}$, determined whether the student knew the difference between right and wrong

- A poorly conducted and documented evaluation was completed to inform the MD process process not only must be done correctly, but the IEP team also must conduct a thorough and appropriate evaluation, assess the appropriateness and implementation of the IEP, and make a good-faith effort to answer the questions required by IDEA ' 97 .

These decisions have important implications for school districts as they use discipline procedures in ways that comply with IDEA ' 97 . We next offer guidelines to assist administrators and IEP teams to meet the requirements of IDEA '97. These guidelines are based on the IDEA ' 97 and implementing regulations as well as principles extrapolated from the due process hearings.

\section{IMPLICATIONS FOR PRACTICE}

Perhaps the most important implications of the discipline provisions of IDEA '97 are those that require IEP teams to take a proactive, problem-solving approach toward addressing the problem behaviors of students with disabilities. IEP teams must become competent in conducting appropriate assessments and evaluations. Furthermore, the IEP team must design and deliver appropriate programming based on positive behavioral interventions and supports to meet these students' needs. This means that school districts will have to employ people who are competent in conducting functional behavioral assessments and developing positive behavior intervention plans to include in students' IEPs.

Finally, IEP teams have to become proficient at developing data-collection systems to determine students' progress toward their behavioral goals. Moreover, instructional decisions should be based on the data collected. As Smith (2000) aptly states, if we cannot acquire these skills, "the legal and financial repercussions of our inability to consistently deliver in the behavioral domain may be high" (p. 411).

With respect to the disciplinary components of IDEA '97, the IDEA '97's limitations on the amount of time that students can be removed from school will come into play only if school personnel and parents cannot work out arrangements regarding an appropriate educational program and placement through the IEP process (Hartwig \& Reusch, 2000; Yell et al., 2000). Therefore, the discipline process must be handled through the IEP process. When parents and school personnel can work together to best meet the needs of the school and the student with behavioral problems, many of the procedural issues we have discussed in this article become moot. That is, parents don't have to resort to the procedural mechanisms for their child's needs to be met.

\section{Develop A Schoolwide Discipline System}

If schools are to become safe and orderly environments, schoolwide discipline systems that represent partnerships between schools, community agencies, and parents and provide 
proactive behavior support to all students are essential (Horner, Sugai, \& Horner, 2000). These systems should include (a) schoolwide rules and procedures for all students and settings, (b) specific-setting procedures for specific school settings (e.g., cafeteria, hallways), (c) classroom procedures for specific teachers and their students, and (d) individual-student procedures for the $1 \%$ to $7 \%$ of students who are most likely to exhibit problem behavior (Sugai, \& Horner, 1999). These schoolwide systems can decrease problem behaviors and encourage appropriate behavior.

Furthermore, individual support systems can include positive behavior support plans to teach socially appropriate behaviors to students with severe problem behaviors. When schools adopt schoolwide policies, they should be included in the IEPs of students with disabilities who exhibit problem behaviors. When a student's parents agree to the IEP, they are consenting to using the school's regular discipline policy. Any changes to the discipline policy, however, should be included in the IEP. The Office of Special Education Programs supported this idea in stating: "In appropriate circumstances the IEP team...might include specific regular or alternative disciplinary measures that would result from particular infractions of school rules" (OSEP Question and Answers, 1999, p. 12589).

\section{Know Procedural Requirements of the Laws}

In addition to the IDEA, administrators and teachers need to be aware of the (a) requirements of Section 504, (b) due process protections that must be followed in suspending or expelling students, and (c) applicable state laws. When problems arise in any of these areas, school districts open themselves to legal difficulties.

Adhering to IDEA procedures has been a persistent challenge for school districts. IDEA contains a number of procedural requirements that school districts must follow. For example, when determining the IAES, the law's procedures require that the IEP team make the decisions regarding a student's educational services. School districts, however, have lost due process hearings because administrators rather than the IEP team made these decisions (e.g., Independent School District \#279, 1999).

Procedural violations do not automatically lead to a school district losing a hearing or case. The procedural violation must be serious enough in the eyes of the hearing officer or judge to have resulted in a student being denied a FAPE. It undoubtedly would be a serious enough violation to constitute the denial of an FAPE if a student exhibits a problem behavior and a school district does not address the behavior in the IEP. IEP teams must address serious problem behavior that impedes a student's learning throughout his or her IEP, in the present levels of performance, in the goals and objectives, and in the special education and supplementary services.
Failing to conduct a manifestation determination or an FBA prior to placing a student in an IAES, for example, would likely be a violation of that student's right to an FAPE. Developing an IEP that addresses these behaviors will help to ensure that the procedural requirements of the law are followed. Merely going through the process of addressing problem behavior, however, will not be sufficient if the behavioral programming is not implemented correctly or does not lead to meaningful educational benefit.

In addition to the federal requirements, IEP teams must understand state requirements and laws. Some states (e.g., California, Iowa, Minnesota) have more stringent requirements regarding the discipline of students with disabilities than does the federal government. In such situations, the more exacting state requirements must be followed.

\section{Train Administrators and Faculty \\ To Meet the Law's Requirements}

Schools districts need to ensure that administrators and faculty are well trained in implementing the changes in IDEA ' 97 . Training is especially important for (a) conducting assessments that lead to educational programming, (b) developing IEPs that contain measurable goals and result in meaningful educational benefits, (c) addressing problem behavior in positive and proactive ways, and (d) using appropriate disciplinary procedures according to the requirements of IDEA '97. It is the responsibility of school districts to ensure that IEP team members are properly prepared to carry out these tasks in accordance with best practices.

Public policy has exceeded the existing knowledge base with respect to the FBA requirements of IDEA '97 (Nelson, Roberts, Mathur, \& Rutherford, 1999). According to those authors, IDEA '97 now requires that school-based teams conduct FBAs, although they currently do not have the knowledge and training to do so. Similarly, Smith (2000) asserted that teachers may not have the necessary competencies to properly implement the behavioral and disciplinary provisions of IDEA ' 97.

We agree with these assessments; however, we also believe that teachers and team members can be trained to use this methodology effectively and efficiently (Drasgow et al., 1999). It will require an increased emphasis on the methods and strategies of behavioral programming during preservice preparation. In addition, school districts will have to provide in-depth inservice training to faculty members who are not familiar with the behavioral requirements of the law. Preservice teachers will require intensive training in assessments, direct and indirect data collection procedures, interpretation of data, and developing, implementing, and evaluating interventions based on data (Drasgow et al., 1999; Scott \& Nelson, 1999; Sugai, Horner, \& Sprague, 1999). 
When IEP teams fail to follow the law's requirements regarding behavioral interventions when writing students' IEPs, the likely result will be inappropriate IEPs and, thus, the denial of an FAPE. The denial of an FAPE, in turn, may, lead to due process hearings, litigation, and application of the law's sanctions against the offending school districts. Preservice and inservice educational opportunities should be provided, therefore, to ensure that members of IEP teams thoroughly understand their responsibilities under IDEA '97 and have the skills to carry them out.

\section{Address Discipline and Positive Behavioral Programming in the IEP}

IDEA '97 emphasizes positive behavioral interventions, supports, and services for students with disabilities who exhibit problem behaviors. The purpose of the positive behavior supports is to develop multicomponent proactive programming that emphasizes skill-building, rather than reactive programming, which relies on crisis management techniques (e.g., time-out, restraint) following the occurrence of problem behaviors. To ensure that our behavioral programs lead to meaningful results requires that IEP teams use ongoing evaluations to monitor a student's progress and to make the appropriate changes when data indicate that a program is not effective.

Thus, IDEA ' 97 requires that IEP teams engage in problem-solving when addressing problem behavior. Addressing problem behavior in a preventive manner requires that IEP teams use an information-gathering, problem-solving team process that includes intense assessment and collaborative planning. Such practices are likely to withstand administrative or judicial scrutiny when challenged in a due process hearing or a court.

IEP teams should address problem behavior at the first signs of serious problems or when school district personnel or family members express concerns about a student's problem behavior (Conroy, Clark, Gable, \& Fox 1999; Drasgow et al., 1999). These efforts will increase the prospect that a student's behavior will improve and also will provide documentation when programming is legally challenged.

\section{Collect Meaningful Data on Student Progress}

Administrators and teachers should collect two types of data with respect to discipline. First, they need to keep thorough records of behavioral incidents, school reactions (e.g., suspensions), and parent contacts. This information pertaining to the school districts and parents' action can prove helpful when a school is legally challenged. Second, IEP teams must collect meaningful data continuously to document student progress toward IEP goals and, thus, to document the program's efficacy. This means that data should be collected during behavioral programming so student progress is continually monitored.

The purpose of data collection is to provide objective evidence of program efficacy, assess student performance, and guide programming decisions (e.g., Deno, 1992; Fuchs \& Fuchs, 1990, Yell \& Drasgow, 2000). IEP teams can ensure that they provide meaningful programming by collecting useful data and by demonstrating that the data were used to guide sound instructional decisions.

Furthermore, IEP teams must make decisions with respect to the nature of the data that will be collected to monitor student progress and to make program adjustments when necessary (Heflin \& Simpson, 1998). Anecdotal data and other subjective procedures are not appropriate for monitoring student progress, and should never be the basis of a data collection system (Yell \& Drasgow, 2000). The most appropriate data collection systems are those from applied behavior analysis (e.g., Alberto \& Troutman, 1999; Wolery, Bailey, \& Sugai, 1988), in which target behaviors can be measured, graphed, and visually inspected to evaluate progress toward goals and objectives.

\section{SUMMARY}

IDEA '97 attempts to balance schools' need to maintain a safe and orderly environment with students with disabilities' right to receive an FAPE. Unfortunately, several inconsistencies in the statute and its regulations have resulted in continued confusion over school districts' responsibility. Future hearings, court rulings, and legislation will provide answers to these still confusing issues. In this article we have examined these issues and offered recommendations to administrators and educators that, we hope, will assist them in meeting the disciplinary requirements of IDEA ' 97 in a legally correct and educationally appropriate manner.

Administrators must ensure that (a) general and special education personnel in their school districts understand the discipline-related requirements of the law, and (b) all school personnel comply with these requirements. Local school officials must realize that when disciplining students with disabilities, the IEP and Section 504 preempt the school's regular disciplinary code if suspension, expulsion, or changes of placement are used. Moreover, in such situations the proper body to address discipline is the IEP team.

Finally, if parents and school personnel can arrive at appropriate solutions to disciplinary problems through the IEP process, there is no need to resort to the measures addressed in this article. If school administrators are diligent in discharging their duties and if IEP team members understand and discharge their responsibilities appropriately, school districts will be able to meet the challenges and opportunities presented in the disciplinary provisions of IDEA ' 97. 


\section{FOcuson Exceptional children}

\section{REFERENCES}

Alberto, P. A., \& Troutman, A. C. (1999). Applied behavior analysis for teachers (5th ed.). Upper Saddle River, NJ: Prentice Hall/Merrill.

Alexander, K. \& Alexander, M. D. (1992). American public school law (3d ed.). St. Paul, MN: West Publishing.

Analysis of Comments and Changes (1999), Federal Register, 64, 12,620.

Board of Education of the Akron Central School District, 28 IDELR 909 (SEA NY 1998).

Conroy, M., Clark, D., Gable, R., \& Fox, J. (1999). A look at IDEA 1997 discipline provisions: Implications for change in the roles and responsibilities of school personnel. Preventing School Failure, 43, 64-70.

Controlled Substances Act, 21 U.S.C. § 812(c).

Curwin, R. L. \& Mendler, A. N. (1988). Discipline with dignity. Alexandria, VA: Association for Supervision \& Curriculum Development.

Deno, S. L. (1992). The nature and development of curriculum-measurement. Preventing School Failure, 36, 5-11.

Department of Education Answers Questions on Regulations (1997, November 21). Special educator. Horsham, PA: LRP Publications.

Doe v. Maher, 793 F2d. 1470 (9th Cir. 1986).

Drasgow, E. \& Yell, M. L. (In press). Functional behavioral assessment: Legal requirements and challenges. School Psychology Review.

Drasgow, E., Yell, M. L., Bradley, R., \& Shriner, J. G. (1999). The IDEA Amendments of 1997: A school-wide model for conducting functional behavioral assessments and developing behavior intervention plans. Education \& Treatment of Children, 22, 244-266.

Dunlap, G., \& Koegel, R. L. (1999). Welcoming introduction. Journal of Positive Behavior Interventions, 1, 2-3.

Federal Criminal Code, 189 U.S.C. $\$ 930$.

Fuchs, D. \& Fuchs, L. S. (1990). Making educational research more important. Exceptional Children, 57, 102-107.

Gorn, D. (1999). What do I do when... The answer book on discipline. Horsham, PA: LRP Publications.

Goss v. Lopez, 419 U.S. 565 (1975).

Hartwig, E. P. \& Reusch, G. M. (1995). How to conduct a manifestation determination. [Video]. Horsham, PA: LRP Publications.

Hartwig, E. P. \& Ruesch, G. M. (2000). Disciplining students in special education. Journal of Special Education, 33, 243-250.

Heflin, L. J. \& Simpson, R. L. (1998). Interventions for children and youth with autism: prudent choices in a world of exaggerated claims and empty promises: Part 2. Legal/policy analysis and recommendations for selecting interventions and treatments. Focus on Autism \& Other Developmental Disabilities, 13, 212-220.

Horner, R., \& Carr, E. (1997). Behavioral support for students with severe disabilities: Functional assessment and comprehensive intervention. Journal of Special Education, 31, 84-104.

Horner, R. H., Sugai, G., \& Horner, H. F. (2000). A schoolwide approach to student discipline. The school administrator, 24, 20-23.

Huefner, D.S. (2000). The risks and opportunities of the IEP requirements under IDEA '97. Journal of Special Education, 33, 195-204.

Independent School District \#279, Osseo Area School, 30 IDELR 645 (SEA MN 1999).

Individuals with Disabilities Education Act, 20 U.S.C. § 1401-1485.

Individuals with Disabilities Education Act Regulations, 34 C.F.R. $\S 300$ et seq.

Katsiyannis, A., \& Maag, J. (1998). Disciplining students with disabilities: Issues and Considerations for Implementing IDEA '97. Behavioral Disorders, 24, 276-289.

Kubick, R. J., Bard, E. M., \& Perry, J. D. (2000). Manifestation determinations: Discipline guidelines for children with disabilities. In C. Telzrow \& M. Tankersley (Eds.), IDEA Amendments of 1997: Practice guidelines for school-based teams (pp. 199-240). Bethesda, MD: National Association of School Psychologists.
Laurens County School District \#55, 31 IDELR 204 (SEA SC 1999).

Martin, J. L. (1999, May). Current legal issues in discipline of disabled students under IDEA: A section by section comment of $\$ 1415(\mathrm{k})$, discipline regulations, and initial case law. Paper presented at LRP's Annual Conference on Special Education Law, San Francisco.

Nelson, J. R., Roberts, N., Mathur, S., \& Rutherford, R. (1999). Has public policy exceeded our knowledge base? A review of the functional behavioral assessment literature, Behavioral Disorders, 24, 169-179.

Office of Special Education Programs. Letter to Anonymous, 30, IDELR, 707 (1999).

O’Neill, R. E., Horner, R. H., Albin, R. W., Sprague, J. R., Storey, K., \& Newton, J. S. (1997). Functional assessment and program development for problem behavior. Pacific Grove, CA: Brooks/Cole Publishing Company.

OSEP Questions and Answers (1999, March 12). Federal Register, 64(48), $12617-12632$.

S-1 v. Turlington, 635 F.2d. 342 (5th Cir. 1981).

Scott, T. M., \& Nelson, C. M. (1999). Functional behavioral assessment: Implications for training and staff development. Behavioral Disorders, 24, 249-252.

Searcy Public Schools, 30 IDELR 488 (OCR 1998).

Senate Report of the Individuals with Disabilities Act Amendments of 1997, cited in Federal Register, 64, 12625 (1999).

Smith, C. R. (2000). Behavioral and discipline provisions of IDEA '97: Implicit competencies yet to be confirmed. Exceptional Children, 66, 403-412.

Sugai, G. \& Horner, R. H. (1999). Discipline and behavioral support: Practices, pitfalls, and promises. Effective School Practices, 17 (4), 10-22.

Sugai G., Horner, R. H., \& Sprague, J. R. (1999) Functional assessmentbased behavior support planning: Research to practice to research. Behavioral Disorders, 24, 253-257.

Telzrow, C. F., \& Naidu, K. (2000). Interim alternative educational settings: Guidelines for prevention and intervention. In C. Telzrow \& M. Tankersley (Ed.), IDEA Amendments of 1997: Practice guidelines for school-based teams (pp. 199-240). Bethesda, MD: National Association of School Psychologists.

Valente, W. D. (2000). Law in the schools (4th ed.). Upper Saddle River, NJ: Merrill/Prentice Hall.

Walker, H. M. (1995). The acting-out child: Coping with classroom disruption. Longmont, CO: Sopris West.

Walker, H. M, Colvin, G., \& Ramsey, E. (1995). Antisocial behavior in school: Strategies and best practices. Pacific Grove, CA: Brooks/Cole.

Wolery, M., Bailey, D. B., \& Sugai, G. M. (1988). Effective teaching: Principles and procedures of applied behavior analysis with exceptional students. Boston: Allyn \& Bacon.

Yell, M. L. (1998). The law and special education. Upper Saddle River, NJ: Merrill/Prentice Hall.

Yell, M. L., \& Drasgow, E (2000). Litigating a free appropriate public education: The Lovaas hearings and cases. Journal of Special Education, 33, 206-215.

Yell, M. L. \& Katsiyannis, A. (2000). Functional behavioral assessment and IDEA '97: Legal and practice considerations. Preventing School Failure, 44, 158-162.

Yell, M. L., Katsiyannis, A., Bradley, R., \& Rozalski, M. (2000). Ensuring compliance with the disciplinary provisions of IDEA '97: Challenges and opportunities. Journal of Special Education Leadership, 13, 3-18.

\section{AUTHORS' NOTE}

For a list of the cases and due process hearings reviewed in this paper, please contact Mitchell Yell at myell@sc.edu. 